\title{
KURZGEFASZTE ANLEITUNG
}

\author{
ZUR

\section{QUALITATIVEN CHEMISCHEN ANALYSE}

3. AUFLAGE

GIESZEN

J RICKER'SCHE VERLAGSBUCHHANDLUNG (ALFRED TÖPELMANN) 1903. 
